\title{
Design and Characterization of a Roof-Mounted Compound Parabolic Concentrator
}

\author{
Anita Ortega*, Subhash Chandra, Sarah McCormack
}

\author{
Solar Energy Applications Group, Department of Civil, Structural and Environmental Engineering, Trinity \\ College Dublin, IRELAND \\ Email: ortegaa@tcd.ie
}

\begin{abstract}
This paper presents the design, fabrication and performance of a roof mounted compound parabolic concentrators (CPC) for electricity generation. A truncated Asymmetric Compound Parabolic Concentrator with concentration ratio of 1.83, acceptance-half angles of $60^{\circ}$ and an absorber width of $125 \mathrm{~mm}$ has been designed, constructed and experimentally characterized on the roof of the Simon Perry Building at Trinity College Dublin, Ireland (53.344295, -6.252416). A CPC and a PV systems were tested under outdoor conditions with 4-cell PV strings. The first challenge was to determine the power generation, efficiency and temperature of both systems and compare the results. The experiment revealed that at solar incident radiation of $800 \mathrm{~W} / \mathrm{m}^{2}$, the CPC system increased the power and efficiency by $34 \%$ (power by factor 1.34) and $22 \%$ (efficiency by factor 1.22) respectively, compared with PV system. However, the solar cell temperature in CPC system increased by $74 \%$ (temperature by factor 1.74). In order to analyze the temperature, a convective cooling CPC system was tested. The result showed that when the temperature increased by $22 \%$ (temperature by factor 1.22) compared with the PV system, the power and efficiency improved by $84 \%$ and $65 \%$, respectively.
\end{abstract}

KEYWORDS: Building integration, Compound parabolic concentrator, Photovoltaics.

\section{INTRODUCTION}

Photovoltaics convert the solar radiation to electrical energy. The efficiency and power output depend of the solar radiation intensity which reaches the solar cell surface. The amount of solar radiation over the solar cell surface can be increased using concentrators [1]. PV concentrators can be classified in four types: Lens concentrator, Mirror concentrator, Reflector concentrator and Static concentrator [2]. An example of reflector concentrator is the compound parabolic concentrator. In this type of concentrator, large portion of the reflector area can be eliminated without reducing the concentration ratio. Also they have the potential to reduce the electricity production cost by concentrating the incoming light into a smaller area of PV [3]. However, the temperature in the compound parabolic concentrator become in an important factor which needs a consideration. In this study, an asymmetric compound parabolic concentrator has been designed, constructed and experimentally characterized for roof integration in Dublin, Ireland. In order to reduce the quantity of reflector material, the CPC was truncated by $70 \%$ leading to a geometrical concentration ratio of 1.83 , as is shown in Figure 1. The system was constructed based in a previous optical performance analysis using race trace technic [4]. The physical and geometrical characteristics are shown in Table 1.

TABLE 1. PHYSICAL AND GEOMETRICAL PROPERTIES OF THE CPC

\begin{tabular}{|c|c|}
\hline Acceptance-half angle & $60^{\circ}$ \\
\hline Absorber (mm) & 125 \\
\hline Refl. 1 (mm) & 155.34 \\
\hline Refl. 2 (mm) & 128.54 \\
\hline Aperture (mm) & 228.43 \\
\hline Geometrical Concentration ratio & 1.83 \\
\hline Truncation Refl. 2 (\%) & 70.02 \\
\hline
\end{tabular}




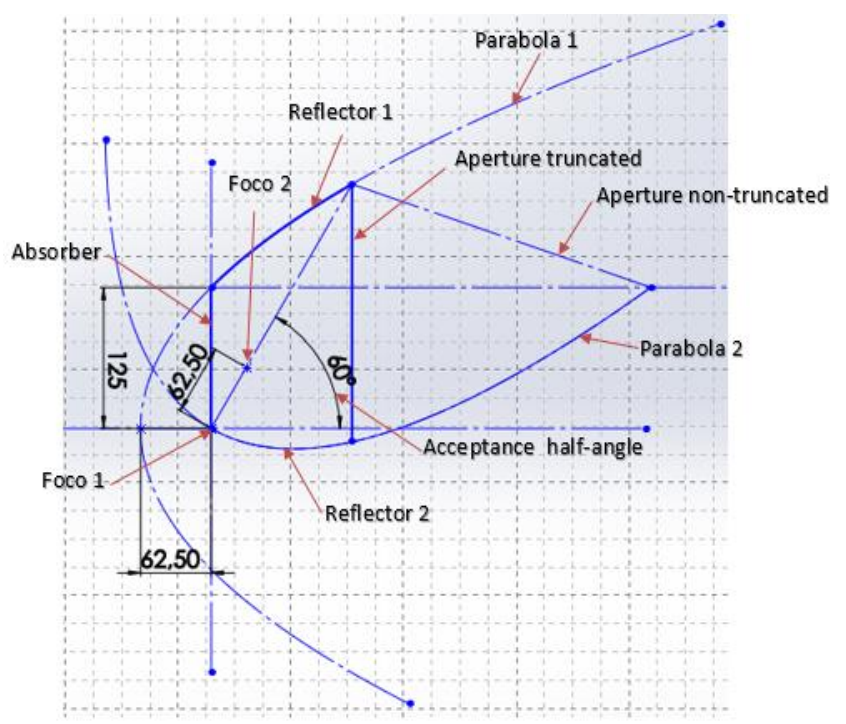

Figure 1. Parabolas which form the CPC system with an acceptance half angle of $60^{\circ}$ generated in SolidWorks

\section{DESIGN, MANUFACTURE AND ASSEMBLY OF THE CPC}

The CPC was composed of a PV absorber, reflector, reflector supports, thermocouples, aperture cover and frame. The materials selection, design and fabrication for each component of the CPC system are described in the following section.

\subsection{Reflective material employed for CPC system}

Aluminium Foil with a reflectivity average of 0.76 and $1 \mathrm{~mm}$ thickness provided Easygrow company was chosen as the reflector of the CPC system due to its low cost and acceptable reflectivity properties.

\subsection{Design and material selection for reflector support and back plate}

The reflector supports and backplate were designed using aluminium. Two designs of reflector support called reflector support south and reflector support north were designed and manufactured from aluminium material with $25 \mathrm{~mm}$ thickness in order to provide strength to the bond and bending surface. For each reflector, six pieces were designed using Autocad and SolidWorks and those designs were transferred to the CNC machine in the workshop at the Mechanical and Manufacturing Department at Trinity College Dublin. In order for easy assembly, each reflector was fixed to the back plate using two screws $M 6 X \emptyset 11 \mathrm{~mm}$. The details of both reflector designs are shown in Figure 2 a). A back plate was designed from aluminium with $6 \mathrm{~mm}$ thickness. The dimensions of the back plate were $706 \times 525 \mathrm{~mm}$ and forty-six holes of $\varnothing 11 \mathrm{~mm}$ were machined to fix the support reflectors, frame and foam. The detailed design of the aluminium back plate is shown in Figure $2 \mathrm{~b}$ ). 
a)

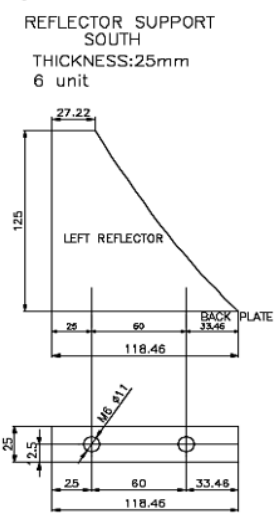

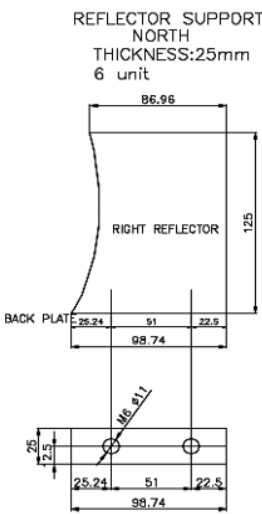

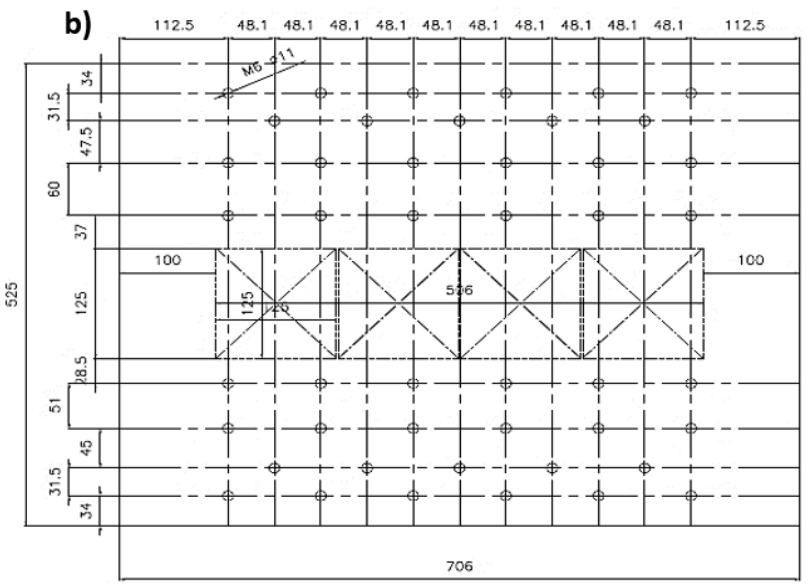

a) Reflector support b) Aluminium back plate

Figure 2. Design details in Autocad

\subsection{Solar cell selection and interconnection}

Monocrystaline bare solettes solar cells, $125 \mathrm{~mm}$ squared manufactured by SunPower were selected for the CPC system and PV system. According to technical specification the solar cells dimensions are $125 \times 125$ $\mathrm{mm}$, with an efficiency of $17.5 \%$, Grade A, short circuit current of $5.15 \mathrm{~A}$, open circuit voltage of $0.515 \mathrm{~V}$ and maximum power output of $2.941 \mathrm{~W}$. Four solar cells in series connection were selected for the CPC system. For the solar cell interconnection, two copper PV ribbons with $2 \mathrm{~mm}$ and $5 \mathrm{~mm}$ width and $0.2 \mathrm{~mm}$ thickness were used. For the soldering process, a leaded solder wire with alloy metal $\mathrm{Sn}-43 \mathrm{~Pb}-14 \mathrm{Bi}$ (Almil Serie: KR15) of $0.65 \mathrm{~mm}$ diameter was used with the soldering iron heated to $260^{\circ} \mathrm{C}$. A flux pen ECO-WORTHY was used to mark the flux of the copper ribbon in order to improve the soldering performance.

\subsection{Thermocouple selection and characterization}

Twenty "K" type thermocouples (chromel-alumel) were used for thermal analysis of the CPC and PV systems. All thermocouples were previously tested all together at $21^{\circ} \mathrm{C}, 40^{\circ} \mathrm{C}, 50^{\circ} \mathrm{C}$ and $60^{\circ} \mathrm{C}$ using a 235 Column Heater Beckman. The results showed a maximum measured deviation of $\pm 0.4^{\circ} \mathrm{C}$ compared with a Thermometer HD 2307.0 RTD.

\subsection{Electric circuit, solar sensor and data collection}

Two electric circuits with the same characteristic were used to collect the values of current and voltage for the CPC system and PV system independently. A resistor of 0.2 ohms with maximum power of $15 \mathrm{~W}$ was used for each circuit. In order to avoid high current, a RS 257-408 shunt with a conversion factor of $20 \mathrm{~A}-200 \mathrm{mV}$ was connected in series and then connected to the data logger. The horizontal solar radiation was recorded using a Kipp and Zonen Sp Lite 2 pyranometer with a sensitivity of $10.2 \mu \mathrm{V} / \mathrm{Wm}$. A data logger (Agilent 3472A $\mathrm{LXI}$ ) was used for the electrical and thermal characterization of the CPC and PV systems. Twenty-five channels were programed and used to measure voltage, current, temperature and solar radiation. The data were recorded every minute.

\section{OUTDOOR CHARACTERIZATION CPC AND PV SYSTEM}

\subsection{Roof assembly}

The CPC and PV systems were installed on the roof, mounted to sub frame rails and then secured with concrete slabs to eliminate the risk of movement in windy conditions. A south orientation was determined using an electronic compass. An insulated box from Campbell Scientific Ltd. Was installed in order to host the electric circuit, the data logger and two 220V plugs. The final location of CPC system and PV system are shown in Figure 3. 


\subsection{Power, efficiency and temperature of CPC and PV system}

The data were recorded on the $17^{\text {th }}$ of July 2017 from 9:00 to 18:00. The weather during testing was generally sunny. The variation of solar radiation and power with the time are shown in Figure 4. A combination graph shows the efficiency and temperature behavior with solar radiation in Figure 5. As it is expected the maximum power and efficiencies values were reached between 12:00 and 14:00. However, by increasing average solar cell temperature, the efficiency of the system was decreased at high solar radiation. From Figure 10 it can be seen that at the maximum radiation of $794 \mathrm{~W} / \mathrm{m}^{2}$ at 13:32 for this day, the power achieved for the CPC system and PV system were $8.6 \mathrm{~W}$ and $8.3 \mathrm{~W}$ respectively and the temperature for the solar cells were $82.6^{\circ} \mathrm{C}$ for the CPC system and $71.4{ }^{\circ} \mathrm{C}$ for the PV system. A maximum CPC system efficiency of $18.6 \%$ was achieved at $744 \mathrm{~W} / \mathrm{m}^{2}$ of solar incident radiation when the power generated by the system was $8.7 \mathrm{~W}$ and the maximum power of $8.9 \mathrm{~W}$ was achieved at $778 \mathrm{~W} / \mathrm{m}^{2}$ when the efficiency was $18.3 \%$. The test shows that the CPC system was $10^{\circ} \mathrm{C}$ higher than the PV panel when both systems were characterized outside.

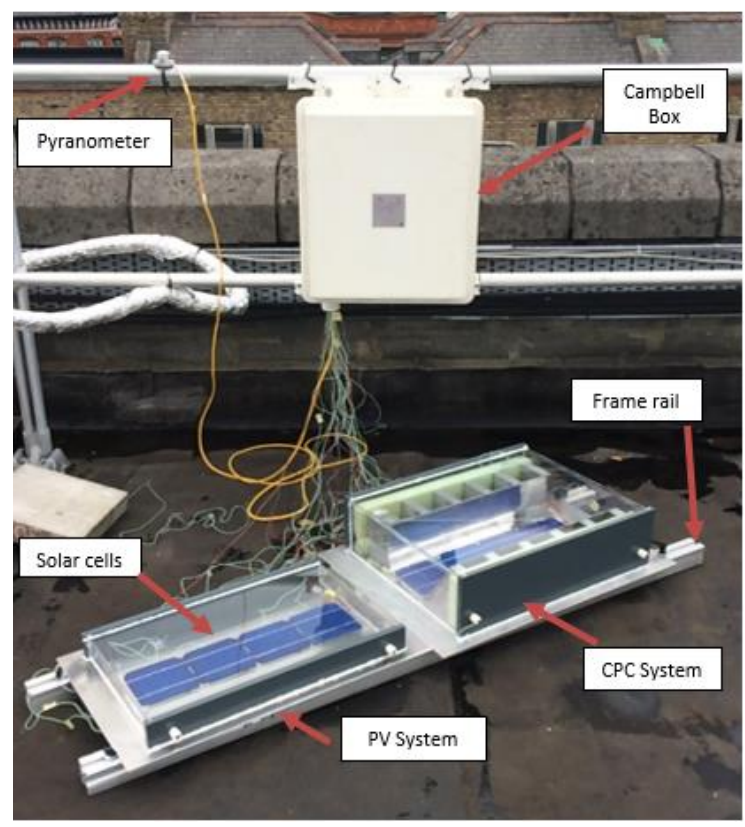

Figure 3. Final location CPC and PV system on the roof at Trinity College Dublin, Ireland

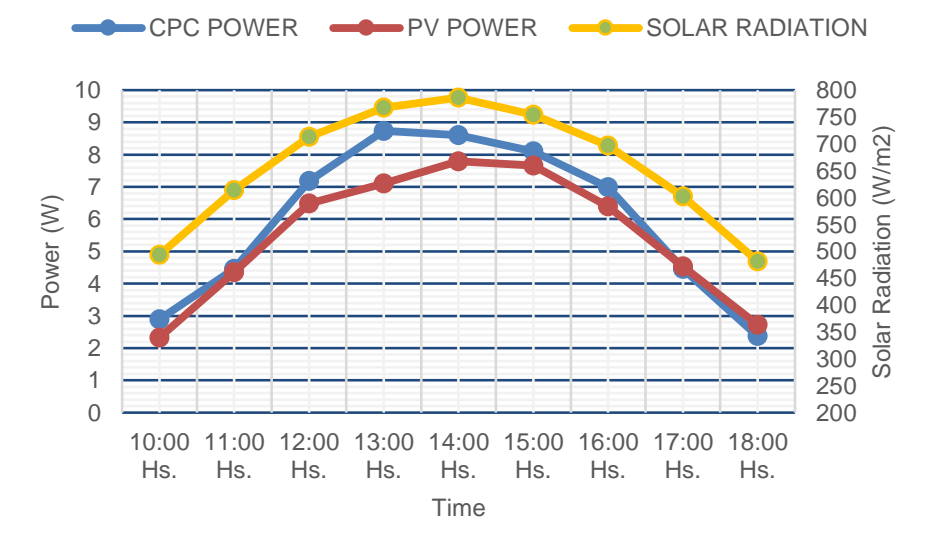

Figure 4. Variation of solar radiation and power with time on the 17th July 2017 


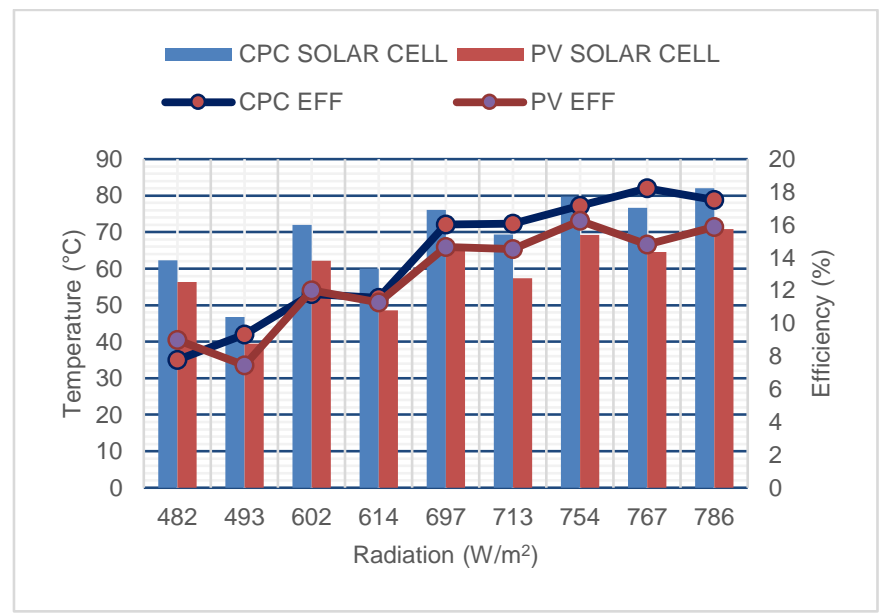

Figure 5. Average temperature, efficiency with radiation for CPC and PV system

\subsection{Effects of the temperature in the CPC system}

A distribution of the temperature in the CPC system is shown in Figure 6 . From the figure it can be seen that the solar cells have the highest temperature values in the system.

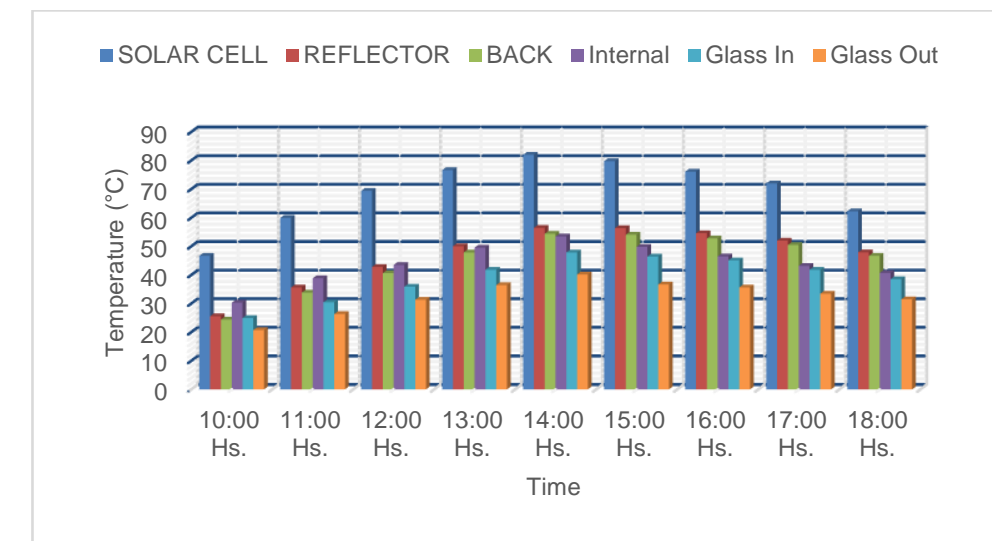

Figure 6. Average temperature distribution in the CPC system on 17th July 2017

\subsection{Analysis with convection cooling system}

For this experiment the aperture cover glass and the two Perspex sheet were removed for the period of nine hours from 9:00 to 18:00 on $18^{\text {th }}$ July 2017 . The weather during testing was generally sunny with intermittent cloud cover. In terms of average, the wind speed on the roof was $1.88 \mathrm{~m} / \mathrm{s}$ and solar cell temperature was 48.5 ${ }^{\circ} \mathrm{C}$ in the cooler CPC system. From Figure 7 and Figure 8, it can be observed that the efficiency and power improved when the CPC system is cooled by convection. Efficiency for the Cooled CPC system and CPC system were $23 \%$ and $17 \%$ respectively at the solar radiation intensity of $800 \mathrm{~W} / \mathrm{m}^{2}$. At the same radiation the temperatures were $55^{\circ} \mathrm{C}$ for Cooling $\mathrm{CPC}$ and $78{ }^{\circ} \mathrm{C}$ for CPC system. In addition, the power produced by the cooled CPC was $11 \mathrm{~W}$ and $8 \mathrm{~W}$ for CPC. These results revealed an improvement in the cooled CPC system over the simple CPC system. At the solar incident radiation of $800 \mathrm{~W} / \mathrm{m}^{2}$ the improvements were of 6 $\%$ in term of efficiency and $3 \mathrm{~W}$ in terms of power output when the temperatures in the solar cells were reduced by $23^{\circ} \mathrm{C}$ with an average wind speed of $1.88 \mathrm{~m} / \mathrm{s}$. 


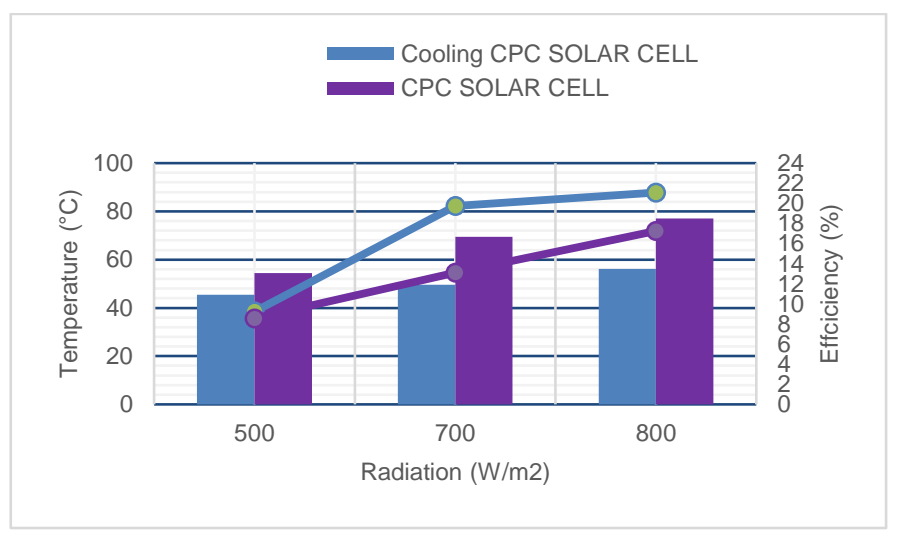

Figure 7. Average temperature and efficiency with radiation for the Cooling CPC system and CPC system

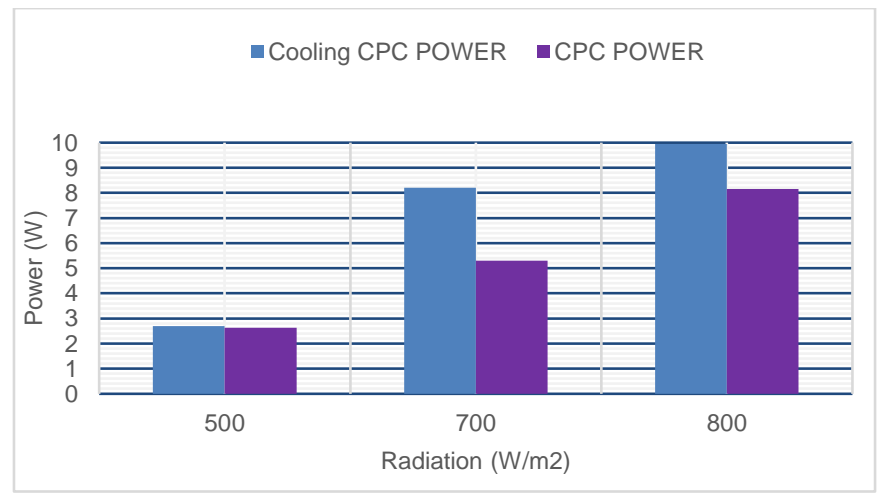

Figure 8. Average power output with radiation for the cooling

\subsection{Analysis of CPC, cooled CPC and PV systems}

Figure 9, 10 and 11 showed the average values of temperature, power and efficiency with radiation for each system. It can clear seen that the efficiency and power for the cooled CPC system is better than the other systems. At $800 \mathrm{~W} / \mathrm{m}^{2}$ solar incident radiation the average power achieved for the cooled CPC system was 5 $\mathrm{W}$ more than the PV system, while the normal CPC was $3 \mathrm{~W}$ more than the PV system. In terms of the efficiency, the cooled CPC system was $9 \%$ more than the PV system, while the normal CPC was $3 \%$ more than the PV system.

- CPC SOLAR CELL - Cooled CPC SOLAR CELL - PV SOLAR CELL

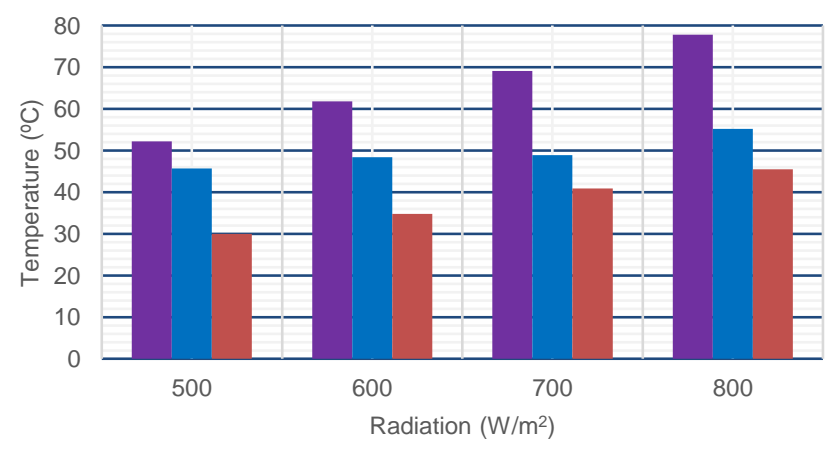

Figure 9. Average temperature between CPC, Cooled CPC and PV systems 


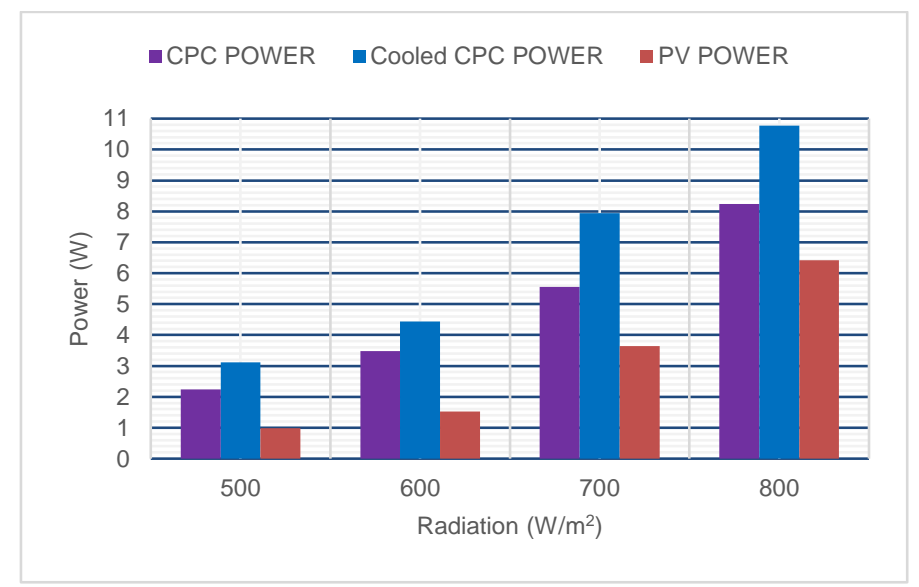

Figure 10. Average power between CPC, Cooled CPC and PV systems

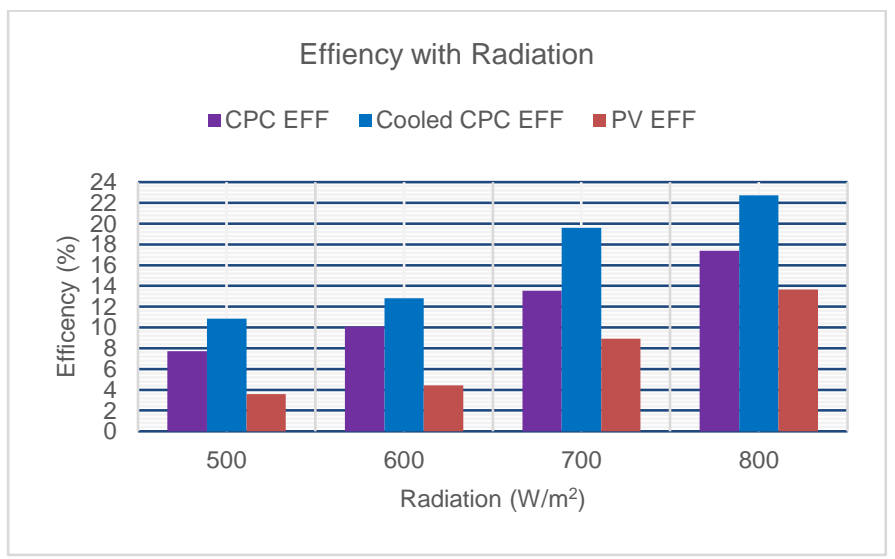

Figure 11. Average efficiency between CPC, Cooled CPC and PV systems

\section{CONCLUSION}

Three different CPC system configurations were manufactured and tested in outdoor conditions and the results were compared with a reference PV system with the same solar cell area and characteristics. The experimental results showed that the efficiency, power and temperature from CPC system were higher than the PV system. The solar cells temperature for the CPC system was decreased when the ambient cooling convection system was added and as a consequence of this the efficiency and power generated improved.

The maximum efficiency, power and temperature achieved by CPC system were $18.6 \%, 8.9 \mathrm{~W}$ and $83.6{ }^{\circ} \mathrm{C}$ respectively. The values represented an increase by $35 \%$ in efficiency, $12 \%$ in power and $14 \%$ in temperature compared with the PV system.

The average efficiency, power and temperature achieved by the cooled CPC system at solar incident radiation of $800 \mathrm{~W} / \mathrm{m} 2$ were $23 \%, 11 \mathrm{~W}$ and $55{ }^{\circ} \mathrm{C}$ respectively. The values represented an increase by $65 \%$ in efficiency, $84 \%$ in power and $22 \%$ in temperature compared with the PV system.

\section{REFERENCES}

1. Mallick T., Optics and heat transfer for asymmetric compound parabolic photovoltaic concentrator for building integrated photovoltaics. PhD thesis. University of Ulster, Newtownabbey, N.I.U.K. 2003.

2. McCormack, S., 'PV Systems \& Solar Thermal Systems'. In J2: Solar Energy Conversion and Applications Lecture notes. October 2016. Dublin: Trinity College Dublin.

3. Rabl A., Optical and thermal proprieties of compound parabolic concentrators. Solar Energy, 1976b;18:497-511.

4. Ortega A. Design and characterization of a roof-mounted compound parabolic concentrator with luminescent down sifting layers. Msc Thesis. Trinity College Dublin, Dublin, Ireland. 2017. 